\title{
Ipratropium bromide in children with asthma
}

\author{
NP MANN, EJ HILLER \\ From the City Hospital, Nottingham
}

\begin{abstract}
Eighteen children between 6 and 14 years of age with perennial asthma were studied over two four-week treatment periods. Ipratropium bromide, given in addition to their current treatment, was compared with placebo using a double-blind crossover technique. The period of treatment with ipratropium was associated with a significant reduction in symptoms during both day and night and significantly higher morning peak expiratory flow rates.
\end{abstract}

Anticholinergic drugs are active bronchodilators in asthma $^{1}$ and are generally administered by aerosol because of side-effects with systemic use. There is experimental evidence pointing to increased vagal activity contributing to bronchospasm ${ }^{2}$ and therapy directed against parasympathetic pathways may have a useful role in treatment of asthma. Ipratropium bromide is thought to work by blocking the binding of acetylcholine at muscarinic receptors in bronchial smooth muscle producing bronchodilatation. It has been shown to be an effective bronchodilator in allergen-induced asthma ${ }^{3}$ and psychogenic asthma ${ }^{4}$ as well as in some patients with exercise-induced asthma. ${ }^{5}$ Such studies have been mainly in adults and we wished to study the use of ipratropium bromide in children with chronic asthma.

\section{Methods}

Twenty children aged 6 to 14 years (mean age $9 \cdot 2$ years) who had attended the paediatric asthma clinic for more than six months were entered into the eight-week trial. Informed consent was obtained from parents and children and ethical committee approval given. There were nine boys and 11 girls. All had perennial asthma with persistent, but not severe, symptoms over the last two months. Eight patients were receiving regular sodium cromoglycate (SCG) or beclomethasone but none required regular systemic steroids. Acute symptoms were treated with bronchodilators as necessary, the majority taking inhaled salbutamol.

Ipratropium bromide, $40 \mu \mathrm{g}$ three times a day (two puffs from the metered aerosol), was given for four weeks and placebo for four weeks in a double-blind crossover manner. The inhalers were coded by the

Address for reprint requests: Dr NP Mann, Children's Department, University Hospital, Queen's Medical Centre, Nottingham NG7 2UH. manufacturers and administered randomly, the code not being broken until the end of the trial. Trial drugs were given in addition to previous regular therapy. Parents and children kept daily records of day and night cough and wheeze, scoring 0 for no symptoms, one for occasional wheeze and/or cough, two for troublesome wheeze and/or cough, and three for very ill with severe wheeze and/or cough. Peak expiratory flow rate (PEFR) was measured in the morning and evening immediately before treatment, using a mini-Wright peak flow meter. A record was kept of bronchodilator dosage and of any other drugs given.

\section{Results}

Eighteen children completed the trial; two failed to keep adequate records. There were no apparent unwanted effects from ipratropium bromide though one patient disliked the taste. Three patients were admitted to hospital during the placebo month with exacerbation of their asthma but none while on active treatment. Three other patients required prednisolone during the placebo month and one during the month on active treatment. Four patients took sodium cromoglycate throughout the study, and four beclomethasone. One patient was started on sodium cromoglycate and another on beclamethasone by their family doctor during their placebo time on the study.

Symptom scores were significantly lower during the ipratropium period for both day and night (table 1) but there was no significant difference between the treatment periods in the percentage of symptom-free days or nights using the signed-rank test.

Peak expiratory flow rate measurements, considered as a mean for each week, were consistently higher during the active treatment period. The increase, however, was small and only reached 
Table 1 Symptom scores

\begin{tabular}{|c|c|c|c|c|c|}
\hline \multirow{2}{*}{$\begin{array}{l}\text { Night } \\
\text { scores }\end{array}$} & \multirow[t]{2}{*}{ Score } & \multicolumn{2}{|c|}{ Ipratropium } & \multicolumn{2}{|l|}{ Placebo } \\
\hline & & Frequency & $\%$ & Frequency & $\%$ \\
\hline & 0 & 181 & $36 \cdot 1$ & 155 & $32 \cdot 2$ \\
\hline & 1 & 240 & $47 \cdot 8$ & 207 & 42.9 \\
\hline & 2 & 76 & $15 \cdot 1$ & 105 & $21 \cdot 8$ \\
\hline & 3 & 5 & $1 \cdot 0$ & 15 & $3 \cdot 1$ \\
\hline & Total & 502 & $100 \cdot 0$ & 482 & $100 \cdot 0$ \\
\hline
\end{tabular}

$p<0.005$.

\begin{tabular}{|c|c|c|c|c|c|}
\hline \multirow{2}{*}{$\begin{array}{l}\text { Day } \\
\text { scores }\end{array}$} & \multirow[t]{2}{*}{ Score } & \multicolumn{2}{|l|}{ Ipratropium } & \multicolumn{2}{|l|}{ Placebo } \\
\hline & & Frequency & $\%$ & Frequency & $\%$ \\
\hline & 0 & 186 & $37 \cdot 1$ & 148 & $30 \cdot 7$ \\
\hline & 1 & 258 & $51 \cdot 4$ & 235 & $48 \cdot 8$ \\
\hline & 2 & 51 & $10 \cdot 2$ & 80 & 16.6 \\
\hline & 3 & 7 & $1 \cdot 4$ & 19 & 3.9 \\
\hline & Total & 502 & $100 \cdot 0$ & 482 & $100 \cdot 0$ \\
\hline
\end{tabular}

Chi square $=17 \cdot 0$.

$\mathrm{p}<0.001$.

Table 2 PEFR measurements

\begin{tabular}{|c|c|c|c|c|}
\hline Evenings & Week 1 & Week 2 & Week 3 & Week 4 \\
\hline $\begin{array}{ll}\text { Ipratropium Mean } \\
\text { Placebo } & \text { Mean } \\
& \text { SE } \\
\text { No significant diffe }\end{array}$ & $\begin{array}{r}221 \cdot 4 \\
16 \cdot 8 \\
202 \cdot 4 \\
15 \cdot 0 \\
\text { ce betwee }\end{array}$ & $\begin{array}{r}223 \cdot 9 \\
18 \cdot 0 \\
215 \cdot 3 \\
16 \cdot 6 \\
\text { PEFRs. }\end{array}$ & $\begin{array}{r}220 \cdot 3 \\
19 \cdot 1 \\
216 \cdot 1 \\
18 \cdot 1\end{array}$ & $\begin{array}{r}221 \cdot 2 \\
17 \cdot 1 \\
210 \cdot 0 \\
16 \cdot 1\end{array}$ \\
\hline Mornings & Week I & Week 2 & Week 3 & Week 4 \\
\hline $\begin{array}{ll}\text { Ipratropium Mean } \\
& \text { SE } \\
\text { Placebo } & \text { Mean } \\
& \text { SE }\end{array}$ & $\begin{array}{r}218 \cdot 2 \\
19 \cdot 4 \\
191 \cdot 0 \\
16 \cdot 5\end{array}$ & $\begin{array}{r}219 \cdot 8 \\
19 \cdot 0 \\
207 \cdot 6 \\
17 \cdot 1\end{array}$ & $\begin{array}{r}217 \cdot 1 \\
22 \cdot 3 \\
206 \cdot 2 \\
19 \cdot 9\end{array}$ & $\begin{array}{r}223 \cdot 8 \\
20 \cdot 9 \\
208 \cdot 2 \\
17 \cdot 5\end{array}$ \\
\hline \multicolumn{5}{|c|}{$\begin{array}{l}\text { Mean overall PEFR higher in ipratropium period than placebo. } \\
p<0.05 \text {. } \\
\text { Time interaction-significant difference between ipratropium }+ \\
\text { placebo in week } 1 \text { only. } \\
\text { p }<0.01 \text {. }\end{array}$} \\
\hline
\end{tabular}

statistical significance for the mornings. When expressed as percentage predicted PEFR for height no significant difference was found (table 2).

There was no significant reduction of bronchodilator usage during the treatment period.

\section{Discussion}

The parasympathetic nervous system appears to be involved in the pathogenesis of asthma in $\operatorname{man}^{6}$ as well as experimental asthma in animal studies. ${ }^{2}$ Using ipratropium bromide, an atropine derivative given locally as an inhaled aerosol, we have demonstrated symptomatic improvement in asthmatic children during a four-week treatment period. The peak flow data are less conclusive but a significant improvement in PEFR did occur in the mornings. Changes in PEFR were small but as a group these patients achieved levels which were around $80 \%$ of predicted means, so a great deal of improvement would not be expected. Similar PEFR results using two-week treatment periods have been shown by Kosche et al, ${ }^{7}$ although symptom scoring was not carried out, while Lin et al demonstrated that ipratropium caused bronchodilatation during a short-term study of asthmatic children and that both small and large airways were affected. 8

The use of this preparation has been limited in children by the inability of many to use pressurised inhalers correctly. Inhalation of a nebulised solution of ipratropium has been shown to be effective in young children ${ }^{9}$ but it is not as effective as salbutamol in blocking exercise-induced bronchoconstriction. The nebulised solution may prove to be valuable in the management of acute asthma, as shown in a recent adult study. ${ }^{10}$ These authors demonstrated a greater improvement in PEFR when ipratropium and salbutamol were given two hours apart than when either drug was given alone. Adult patients with chronic asthma ${ }^{11}$ also showed a considerably greater improvement in $\mathrm{FEV}_{1}$ when these two drugs were given together over a three-day period than when either was used alone, so there seems good reason to use this combination.

The length of action of ipratropium bromide is two and a half to five hours, depending on the dose given. ${ }^{12}$ Our patients were given the drug three times a day, and perhaps more frequent treatment would have been more effective.

Our results suggest that ipratropium bromide may be of value in the management of asthma in children. It may have a role in the prevention of "morning dipping" and further studies of this, and of its use in acute asthma, would be of interest.

We thank Dr Vladimir Pucholt for help with the study, Boehringer Ingelheim for the coded inhalers and statistical advice, and Mrs Stephanie Tyrrell for secretarial help.

\section{References}

${ }^{1}$ Altounyan REC. Variation of drug action on airway obstruction in man. Thorax 1964;19:406-15.

${ }^{2}$ Gold WM, Kessler GF, Yu YC. Role of the vagus in experimental asthma in dogs. J Appl Physiol 1972;33: 719-25.

${ }^{3}$ Cockcroft DW, Ruffin RE, Hargreave FE. Effect of SCH 1000 in allergen-induced asthma. Clin Allergy 1978;81 : 361-72.

4 Rebuck AS, Marcus HI. SCH 1000 in psychogenic asthma. Scand J Respir Dis 1979;103:186-91.

${ }^{5}$ Simonsson BG. Acute effects of ipratropium bromide (ITBR, SCH 1000, Atrovent), a review of previous studies. Scand J Respir Dis 1979;103:130-42.

- Goed WM. The role of the parasympathetic nervous system in airways disease. Postgrad Med J 1975 ;51 :53-62.

${ }^{7}$ Kosche F, Stemmann EA. Peak flow measurements following SCH 1000 MDI in children with reversible airways obstruction. Postgrad Med J 1975;51:127-8. 
${ }^{8}$ Lin MT, Lee-Hong E, Collins-Williams C. A clinical trial of the bronchodilator effect of SCH 1000 aerosol in asthmatic children. Ann Allergy 1978;40:326-32.

${ }^{9}$ Milner AD. Bronchodilator drugs in childhood asthma. Arch Dis Child 1981;56:84-5.

${ }^{10}$ Ward MJ, Fentem PH, Roderick-Smith WH, Davies D. Ipratropium bromide in acute asthma. Br Med J 1981;
282:598-600.

${ }^{11}$ Lightbody IM, Ingram CG, Legge JS. Ipratropium bromide, salbutamol and prednisolone in bronchial asthma and chronic bronchitis. $\mathrm{Br} J$ Dis Chest 1978;72: 181-6.

12 Gross NJ. SCH 1000: A new anti-cholinergic bronchodilator. Am Rev Respir Dis 1975;112:828.

\section{REGISTER OF RARE PULMONARY}

\section{DISEASES}

The British Thoracic Association is keeping a register of a number of rare pulmonary diseases occurring in Britain. Dr Duncan Geddes, co-ordinator of this project, would be grateful if physicians in Britain looking after patients with one of the following diseases could contact him at the Brompton Hospital, Fulham Road, London SW3 6HP:

\section{Alveolar proteinosis}

Wegeners granuloma and similar granulomatous diseases

Lymphangiomyomatosis

Histiocytosis X

Idiopathic pulmonary haemosiderosis

Alveolar microlithiasis 